\title{
Perspectives
}

\section{Biologically Active Atrial Peptides}

\author{
Barbara J. Ballermann and Barry M. Brenner \\ Laboratory of Kidney and Electrolyte Physiology and Department of Medicine, Brigham and Women's Hospital, \\ and Harvard Medical School, Boston, Massachusetts 02115
}

\section{Introduction}

Cardiac atria have long been suspected of participating in the regulation of extracellular fluid volume (1). Expansion of the extracellular fluid volume fails to elicit an increase in urine flow when atrial stretch is prevented (2). Conversely, inflation of a balloon within the right atrium, even in the absence of extracellular fluid volume expansion, results in enhanced urine flow and salt excretion (3), and natriuresis and diuresis frequently accompany paroxysmal atrial tachyarrhythmias $(4,5)$. The renal response provoked by atrial distension or atrial tachycardias has usually been ascribed to reflex stimulation of neural stretch receptors located in the subendocardium (6) but a humoral mediator has also been considered (1). In 1981, DeBold et al. (7) provided direct evidence for the latter by showing that saline extracts of cardiac atria, but not ventricles, elicit a marked increase in urinary salt and water excretion when injected into normal rats.

\section{Terminology}

The atrial factor, now known to be a polypeptide, has variously been termed atrial natriuretic factor (8), atrial natriuretic polypeptide (9), cardionatrin (10), atriopeptin (11), auriculin (12), and atrin (13). Furthermore, several natriuretic peptides of different molecular weights have been isolated from atria. The various atrial peptides possessing natriuretic activity share a common amino acid sequence, with differences emerging only in the length of $\mathrm{NH}_{2}$-terminal and $\mathrm{COOH}$-terminal extensions (Table I). For clarity, this review will refer to all of these peptides by the generic term atrin. The specific sequence for each distinct peptide will be indicated by subscripts, atrin ${ }_{1-28}$ serving as the reference moiety. When reference to a specific sequence is not intended or required, the general term atrin will be used.

\section{Biosynthesis}

The biosynthesis of atrin resembles that of most other secreted peptides. Specific messenger RNA (mRNA) ${ }^{1}$ is transcribed from the gene encoding the atrin precursor molecule, and translated

Address reprint requests to Dr. Ballermann, Royal Victoria Hospital, 687 Pine Avenue West, Montreal, Quebec, Canada H3A 1 A 1.

Received for publication 13 August 1985.

1. Abbreviations used in this paper: AVP, arginine vasopressin; cAMP, cyclic AMP; cGMP, cyclic guanosine monophosphate; dDAVP, nonpressor analog of vasopressin; GFR, glomerular filtration rate; mRNA, messenger RNA; RBF, renal blood flow; RVR, renal vascular resistance; SHR, spontaneously hypertensive rats.

J. Clin. Invest.

(c) The American Society for Clinical Investigation, Inc.

$0021-9738 / 85 / 12 / 2041 / 08 \quad \$ 1.00$

Volume 76, December 1985, 2041-2048 to a pre-pro-atrin sequence containing a hydrophobic signal peptide at the amino terminus. Cleavage of the signal peptide results in large molecular weight pro-atrin, which is further processed to biologically active lower molecular weight atrin (Fig. 1).

The structural properties of the gene encoding atrin were recently delineated (14-18). The gene consists of three exons (translated sequences) interrupted by two introns (intervening, untranslated sequences), and has the organization of a typical eukaryotic gene. The first exon encodes the signal peptide in addition to the first 16 amino acids of pro-atrin. The second exon encodes the remainder of the pro-atrin molecule except the carboxy-terminal tyrosine, which is encoded by the third exon. The nucleotides that encode the terminal tyrosine in the human gene are followed by a stop codon, whereas in rodents, codons for two additional arginine residues follow. The carboxyterminal arginine residues of rodent pre-pro-atrin likely represent a protease cleavage site. The introns of the atrin precursor gene contain splice signals adjacent to the exons, which are required for mRNA processing before translation, and the second intron contains a region thought to represent a glucocorticoid receptor site $(15,16,18)$ (Fig. 1). The atrin gene seems to be very actively transcribed, as $1-3 \%$ of mRNA contained in atrial myocytes represents pre-pro-atrin mRNA $(14,19)$. Changes in the extracellular fluid volume regulate atrin biosynthesis by altering the rate of transcription, as demonstrated by the findings that atrial pre-pro-atrin mRNA content is significantly reduced by fluid deprivation and is elevated by dietary salt excess $(20,21)$.

\section{Molecular structure}

Pre-pro-atrin consists of 151 amino acid residues in humans, and 152 in rat and mouse (18) (Fig. 1). After signal peptide cleavage, pro-atrin consists of 126 amino acid residues. The signal peptide is thought to be required for transport across endoplasmic reticulum. Pre-pro-atrin sequences were deduced from DNA clones complementary to atrial mRNA (22-26). Human and rat pro-atrin sequences are nearly $87 \%$ homologous, although greater differences exist in the signal peptide $(15,22)$. The prohormone contains a glycosylation site (18) and two potential protease cleavage sites $(18,20,26)$ considered important for the formation of biologically active atrin.

Several natriuretic peptides of different molecular weights have been isolated from mammalian atria $(9,10,27-34)$. A $28-$ amino acid polypeptide, atrin $_{1-28}$, corresponding to the carboxyterminal end of pro-atrin, was isolated from human atria (9, 10). A similar sequence obtained from rat atria differs from human atrin ${ }_{1-28}$ by a single substitution of isoleucine for methionine at position $12(31)$. Several smaller peptides were also obtained from rat atria; all are derived from the carboxy terminus of proatrin, with variations in size most likely reflecting different de- 
Table I. Terms Applied to Pro-atrin and Various Atrin Sequences

\begin{tabular}{lll}
\hline & Amino-terminal & Carboxy-terminal \\
\hline Cardionatrin I & $\operatorname{Asp}(+78)$ & $\operatorname{Tyr}(+126)$ \\
Cardionatrin & $\operatorname{Ser}(+99)$ & $\operatorname{Tyr}(+126)$ \\
Atriopeptin I & $\operatorname{Ser}(+103)$ & $\operatorname{Ser}(+123)$ \\
Atriopeptin II & $\operatorname{Ser}(+103)$ & $\operatorname{Arg}(+125)$ \\
Atriopeptin III & $\operatorname{Ser}(+103)$ & $\operatorname{Tyr}(+126)$ \\
Atriopeptigen & $\operatorname{Asn}(+1)$ & $\operatorname{Tyr}(+126)$ \\
Alpha-human ANP & $\operatorname{Ser}(+99)$ & $\operatorname{Tyr}(+126)$ \\
Gamma-human ANP & $\operatorname{Asn}(+1)$ & $\operatorname{Tyr}(+126)$ \\
Alpha-rat ANP & $\operatorname{Ser}(+99)$ & $\operatorname{Tyr}(+126)$ \\
Gamma-rat ANP & $\operatorname{Asn}(+1)$ & $\operatorname{Tyr}(+126)$ \\
Auriculin & $\operatorname{Arg}(+102)$ & $\operatorname{Arg}(+125)$ \\
ANF 1-33 & $\operatorname{Leu}(+94)$ & $\operatorname{Tyr}(+126)$ \\
ANF 3-33 & $\operatorname{Gly}(+96)$ & $\operatorname{Tyr}(+126)$ \\
ANF 8-33 & $\operatorname{Arg}(+102)$ & $\operatorname{Tyr}(+126)$ \\
\end{tabular}

Numbers in parentheses give the location of amino-terminal and carboxy-terminal amino acid residues within the pro-atrin sequence shown in Fig. 1.

grees of proteolysis during isolation procedures. Despite initial uncertainty concerning the various atrin sequences present in plasma, it now appears that only a single peptide is released from rat and human atria (35-39) and evidence at this time favors atrin fi-28 $_{1}$ as the predominant circulating moiety in human and rat plasma (39-41).

Biologic activity of atrin resides in a 17-amino acid ring formed by a disulfide bridge connecting two cysteine residues at positions 7 and 23 (42), although full vasoactive and natriuretic activities also require the carboxy-terminal Phe-Arg $(29,43)$. Biologic activity of atrin is abolished by reduction and carboxymethylation of the disulfide bridge (33). Furthermore, treatment of atrin with dithiothreitol followed by alkylation with iodoacetamide abolishes binding to specific atrin receptors in adrenal glomerulosa membranes (44). Absence of the carboxy-terminal Phe-Arg reduces, but does not abolish, vasorelaxant and natriuretic activity (43). Amino-terminal residues beyond the disulfide bridge are not necessary for biologic action; elongation at the amino terminus, however, to very large sequences, such as proatrin itself, is associated with loss of activity (45).

\section{Intracellular storage}

One of the early clues to the existence of an atrial secretory product was the finding of characteristic granules in myocytes of mammalian atria $(46,47)$. These granules are clustered at the nuclear poles (47) and have histological staining properties unique to proteins (48). Immunocytochemical techniques using specific antibodies directed against peptide fragments of partially purified atrin, against atrin ${ }_{5-28}$, and against an $\mathrm{NH}_{2}$-terminal fragment of pro-atrin, have shown that immunoreactive material is present within mammalian atrial but not ventricular myocytes $(49,50)$ and is localized in atrial granules $(50)$. The presence of pro-atrin immunoreactivity in atrial granules strongly suggests that atrin is stored at least in part as the large molecular weight prohormone. Since antibodies directed against atrin 5-28 $_{\text {or }}$ carboxy-terminal atrin fragments also interact with other peptides sharing this same sequence including pro-atrin, it is not certain whether storage granules also contain lower molecular weight forms. The fact that extracts of atria contain large molecular weight natriuretic peptides that require activation by proteolytic enzymes (51) supports the view that atrin is stored as a relatively inactive prohormone. Atrial myocyte granule content varies depending on salt and water intake $(52,53)$. In water-deprived rats, DeBold noted a positive correlation between hematocrit and the percentage of cytoplasmic volume occupied by granules, suggesting that water deprivation results in a decrease of granule release and/or an increase in the rate of granule formation (53). Immunocytochemical techniques have also demonstrated proatrin-like material in several locations within the central nervous system, suggesting that atrin biosynthesis and storage take place at these sites as well $(11,54)$.

\section{Control of atrin secretion}

In response to high atrial perfusion pressure, rat heart-lung preparations in vitro release a substance into the perfusate that induces natriuresis and diuresis when infused into bioassay rats (55). Similarly, rabbit hearts perfused in vitro release a factor into the coronary venous effluent that relaxes rabbit aortic and chick rectum smooth muscle strips (56). Chromatographic analysis of the effluent revealed a small peptide similar to atrin ${ }_{5-28}$, whereas peptides resembling the large molecular weight fractions isolated from homogenized atria were absent, which supports the notion that atrin is stored as a large prohormone, but only a smaller, biologically active molecule is released (56). Increments in mean right atrial pressure of isolated rat hearts resulted in an increase of immunoreactive atrin-like material in the perfusate (35). Humoral agents have also been shown to stimulate atrial myocyte atrin release. Arginine vasopressin (AVP), phenylephrine, and angiotensin II infusion in vivo produced a marked, though transient, increase in plasma immunoreactive atrin levels (57). The nonpressor analog of vasopressin (dDAVP) elicited no response, and a specific antagonist of the pressor AVP receptors abolished the AVP response (57). Release of atrin-like bioactivity from rat atria in vitro by AVP but not dDAVP, and by epinephrine, suggests direct stimulation of atrin secretion via activation of specific vasopressin and alpha-adrenoceptors on atrial myocytes (58).

Radioimmunoassays for atrin have confirmed the presence of immunoreactive atrin in rat and human plasma $(35,38)$. Chromatographic analysis has consistently shown single peaks in human plasma $(38,39,41)$, and one major peak with smaller amounts of large molecular weight atrin in rat plasma $(31,33)$. In normal humans, circulating atrin concentrations of $7.5 \mathrm{pM}$ $(23 \mathrm{pg} / \mathrm{ml})(41)$ and $21 \mathrm{pM}(63 \mathrm{pg} / \mathrm{ml})(38)$ have been reported. A high salt diet in humans is associated with significantly higher plasma atrin concentrations than a low salt diet (59), and acute infusion of a saline load has been shown to nearly double plasma atrin levels (41). Atrial pacing (38) and paroxysmal atrial tachyarrhythmias (60) elevate circulating atrin concentrations and, in patients with congestive heart failure, plasma-atrin levels were markedly elevated above normal levels (59), indicating that chronic elevation of atrial pressures may lead to hypersecretion of atrin. Reports of atrin concentrations in rat plasma have been variable, with levels ranging from 20 to $550 \mathrm{pM}(35,37,61)$. Discrepancies may be accounted for by differences in anesthetic agents used, the variable effectiveness of proteolytic enzyme inhibition, varying degrees of atrin recovery during extraction, and specificity of antibody employed. Circulating levels of immunoreactive atrin increase in response to acute extracellular fluid volume expansion (35) and chronic dietary salt excess (61). Administration of desoxycorticosterone in the rat leads to a rise 


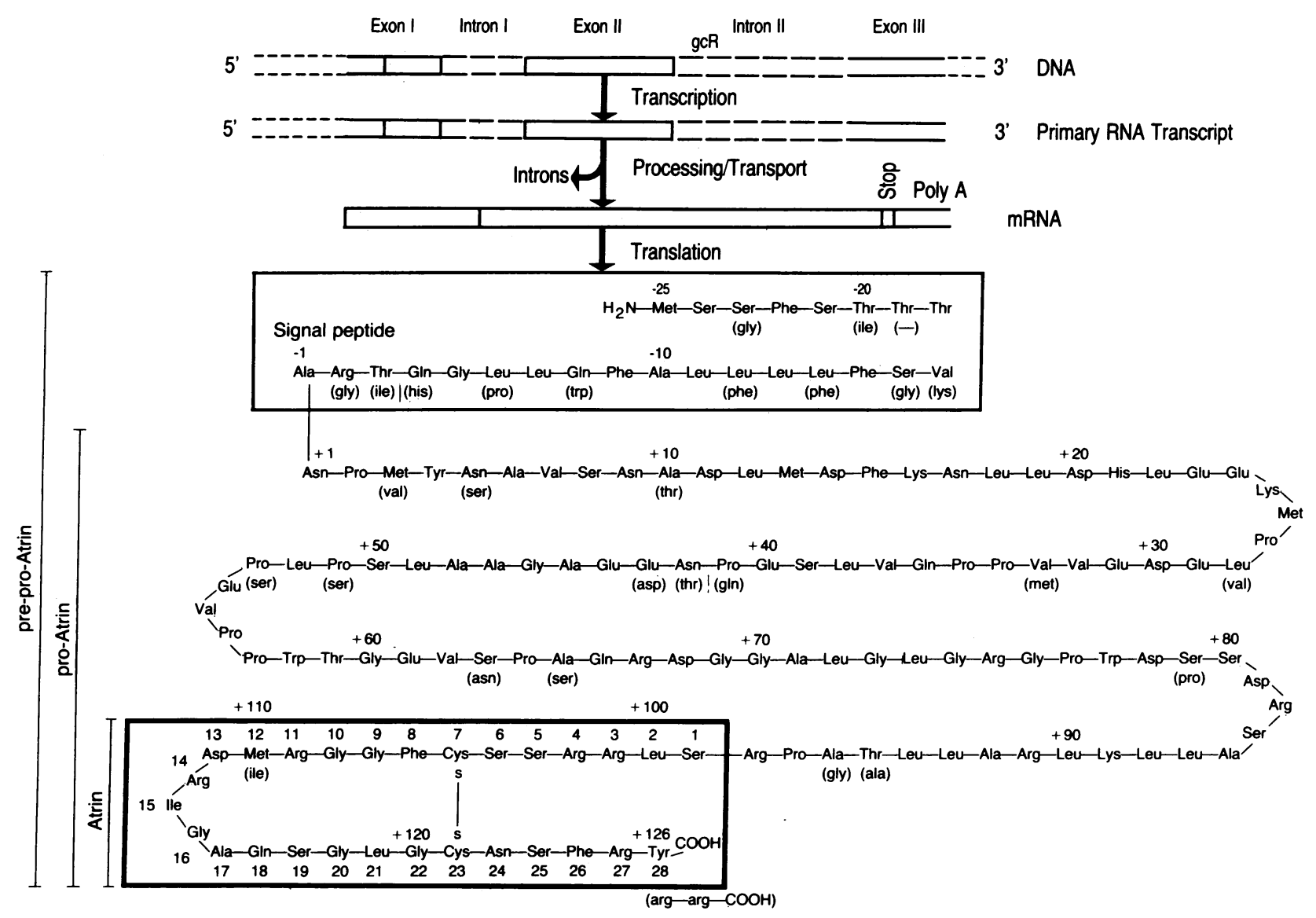

Figure 1. Atrin biosynthesis and structure. $g c R$ indicates the location of the putative glucocorticoid receptor on intron II of the pre-pro-atrin gene. Stop indicates the location of the stop codon, and Poly $A$ reflects the polyadenylation site of the pre-pro-atrin mRNA. The amino acid sequence of human pre-pro-atrin is shown, with substitutions of

in plasma atrin concentrations within $12 \mathrm{~h}$, which suggests that atrin also participates in the phenomenon of mineralocorticoid escape (62). Thus, the diuretic and natriuretic responses to atrial distension by mechanical stretch or by acute volume expansion, the demonstration that atrin-like material is released from the heart in response to increments in right atrial pressure, in response to pacing and paroxysmal atrial tachycardia, and the increase in circulating levels of immunoreactive atrin with acute and chronic extracellular fluid volume expansion all suggest that atrin is an important humoral component of extracellular fluid volume homeostasis.

\section{Atrin receptors}

Autoradiographic studies have shown dense accumulation of radiolabeled atrin in renal glomeruli and in medullary and papillary vasa recta in the rat (63), as well as several locations within the central nervous system (11), suggesting specific atrin receptors in these locations. Specific binding sites for atrin have also been described by radioligand binding techniques in a variety of target tissues, including crude membranes prepared from bovine and rat adrenal glomerulosa $(44,64)$, rat mesenteric artery $(64)$, and rabbit aorta (65), from rat and rabbit kidney (65) and cultured renal epithelial (LLC PK 1 ) cells, derived from pig kidney (65). Binding sites in intact tissues and cells have also been demonstrated in isolated rat renal glomeruli and homogeneous cultures amino acids in rat pre-pro-atrin given in parentheses. Amino acid residues in the signal peptide are assigned negative numbers -25 through -1 ; amino acid residues in the pro-atrin sequence are assigned positive numbers +1 through +126 . The atrin ${ }_{1-28}$ sequence in the heavy box is thought to be the circulating form of biologically active atrin.

of rat glomerular mesangial cells (66), cultured rat aortic smooth muscle cells $(67,68)$, and cultured bovine aortic smooth muscle and endothelial cells (69). These sites bind atrin with high affinity, as reflected by equilibrium dissociation constants ranging in the various preparations from 0.05 to $2 \mathrm{nM}$. Atrin binding sites are saturable at concentrations of the specific agonist in the range of 5-10 $\mathrm{nM}(65,67,68)$, and exhibit a high degree of specificity for atrin in that angiotensin II, vasopressin, somatostatin, parathyroid hormone, and glucagon among many other unrelated peptides do not compete for the binding site (44, 65-67).

Various atrin sequences have been examined to determine the structural requirements for receptor occupancy. The aminoterminal sequence of atrin up to the disulfide bridge is not required for binding activity, as atrin ${ }_{7-28}$ competes as well as atrin $_{1-28}$ for the atrin binding site in glomerular and vascular smooth muscle cells $(66,68)$. Loss of the carboxy-terminal Arg-

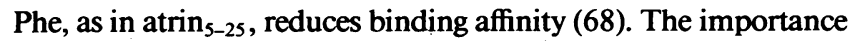
of the disulfide bridge for receptor binding affinity is reflected by the lack of competition of atrin ${ }_{8-28}(68)$ and atrin ${ }_{13-28}(66)$ for the receptor, and by the demonstration that reduction of the disulfide bridge is associated with loss of binding activity (44, 68 ). Whether methionine or isoleucine are present at position 12 , as is the case for human and rat atrin, respectively, does not alter binding activity (66); however, the presence of the sulfoxide derivative of methionine at position 12 is associated with marked 
reduction in receptor binding affinity, which suggests that a hydrophobic residue within the ring structure of atrin is necessary for high-affinity interaction with the receptor (68).

The binding activity of different atrin analogs correlates well with the stimulation of cyclic guanosine monophosphate (cGMP) production in the cells expressing the receptor $(66,68)$. Of note, the cGMP response requires larger atrin concentrations than are needed for maximal binding. These findings suggest that activation of guanylate cyclase, although receptor-mediated, may not be directly coupled to the atrin receptor (66).

That atrin binding sites are present on the surfaces of cultured aortic smooth muscle and endothelial cells is suggested by highaffinity atrin binding to intact cell monolayers $(67,69)$, although clear-cut evidence exists only in cultured glomerular mesangial cells, where atrin bound with high affinity at $4^{\circ} \mathrm{C}$, conditions under which internalization does not occur, and where atrin binding was $>90 \%$ reversible in intact cells (66). Cell surface receptors were not found in glomerular epithelial cells (66), or in LLC-PK ${ }_{1}$ cells (Ballermann, B. J., unpublished observations), the latter previously reported to exhibit binding sites in a particulate fraction prepared from cell homogenates (65). In cultured aortic smooth muscle cells, exposure of cells for $24 \mathrm{~h}$ to atrin $_{1-28}$ leads to a marked decline in receptor density (68). Also, rats given a low-salt diet, which suppressed plasma levels of atrin, had a fourfold higher glomerular atrin receptor density compared with rats fed a high-salt diet in which circulating levels of atrin were also high (66).

Photoaffinity labeling of rat kidney membrane atrin receptors followed by solubilization and electrophoresis on sodium dodecyl sulfate-polyacrylamide gels has shown this receptor to be a glycoprotein of $\sim 140 \mathrm{kD}(70)$.

\section{Effects on cyclic nucleotides}

Atrin stimulates the accumulation of cGMP in a number of tissues, and it has been suggested that this cyclic nucleotide is the intracellular mediator of atrin action (71). Injection of atrial extracts into bioassay rats resulted in a rise of plasma and urinary cGMP levels, with a large proportion of the urinary cGMP due to renal production (72). Measurement of renal arterial and venous cGMP levels indicates, however, that the source of plasma cGMP with atrin infusion is not the kidney (73). Atrin-induced cGMP accumulation in the kidney correlates well with the distribution of particulate guanylate cyclase. The greatest cGMP accumulation occurred in glomeruli, small cGMP increments were seen in thick ascending limbs of Henle and in collecting ducts, and no atrin-stimulated CGMP accumulation was detected in proximal tubules (74). The specific action of atrin on particulate, but not soluble, guanylate cyclase activity in rat kidney, aorta, lung, liver, intestine, and testes has also been reported, with half-maximal activation of guanylate cyclase activity at concentrations of $\sim 10 \mathrm{nM}$ (71). In vascular smooth muscle preparations, cGMP accumulation is associated with loss of smooth muscle tone (75); also, the presence of methylene blue, an inhibitor of guanylate cyclase, reduces the vasorelaxant activity of atrin (76). The inhibition of contraction and the stimulation of cGMP accumulation in vascular smooth muscle are independent of intact endothelium $(75,76)$. In cultured vascular smooth muscle cells and in isolated rat renal glomeruli, a strong correlation between atrin binding to specific receptors and cGMP accumulation was demonstrated $(66,68)$. Cultured papillary collecting duct cells also respond to atrin with increased accumulation of CGMP, a finding that was interpreted to indicate that these cells possess receptors for atrin and that atrin acts directly on the papillary collecting duct in vivo (77).

Thus, experimental evidence suggests that atrin, by interaction with specific cell-surface receptors, activates guanylate cyclase, resulting in the production of cGMP which, in turn, serves as a second messenger to inhibit smooth muscle cell contraction, and perhaps other events in other cell types. There are observations, however, which temper the above conclusion. First, half-maximal occupancy of atrin receptors in most tissues occurs at atrin concentrations below $1 \mathrm{nM}$. Also, half-maximal smooth muscle relaxation is observed at atrin concentrations in the range of 0.1-1 nM (78), and half-maximal inhibition of aldosterone secretion occurs at atrin concentrations of $\sim 2 \mathrm{nM}(79)$. However, threshold concentrations of atrin required to elicit a cGMP response have been on the order of $5 \mathrm{nM}$, with half-maximal stimulation at $10 \mathrm{nM}$ or above $(66,68,71,74)$. This discrepancy in the dose-response curves suggests that guanylate cyclase activation may only be a secondary phenomenon triggered by atrin receptor occupancy. Alternatively, if cGMP is indeed the second messenger mediating atrin action, increments in cell cGMP too low to measure would have to account for the entire physiological response.

Inhibition of adenylate cyclase activity by atrin has also been reported. In particulate fractions from aorta, mesenteric artery, and renal artery homogenates, atrin ${ }_{3-28}$ inhibited basal and hormone-stimulated adenylate cyclase activity in a dose-dependent fashion, with half-maximal inhibition at atrin concentrations of $0.1-1 \mathrm{nM}(80)$. Since inhibition of forskolin and sodium fluoridestimulated adenylate cyclase was also seen, it was concluded that atrin does not interfere directly with hormone receptors stimulatory to adenylate cyclase (80). A similar inhibitory action of atrin on adenylate cyclase activity in anterior and posterior pituitary homogenates was also reported (81). Others have failed to find an effect of atrin on adenylate cyclase activity in kidney homogenates (71), on urinary cAMP excretion (72), or on cAMP accumulation in rabbit aortic strips $(75,76)$, which suggests that inhibition of adenylate cyclase may not be a universal phenomenon.

\section{Vascular actions}

A prominent physiologic effect of atrin is the inhibition of smooth muscle contraction. Rabbit aortic and chick rectum smooth muscle strips in vitro, contracted with norepinephrine and carbachol, respectively, lose contractile tone when atrial extracts from rats or humans are applied (51). More recent use of defined, synthetic atrin sequences has confirmed the specific spasmolytic action of atrial peptides on smooth muscle in vitro. In rabbit aortic strips, sequences lacking the carboxy-terminal Phe-Arg residues appear several orders of magnitude less potent than atrin sequences possessing this dipeptide moiety $(29,82)$. This structural requirement was thought not to be necessary for the effects of atrin on chick rectum smooth muscle or on natriuresis $(29,82,83)$. Recent reevaluation of this issue has shown, however, that removal of carboxy-terminal Phe-Arg residues markedly reduces chick rectum smooth muscle relaxation and renal natriuretic activity $(43,84,85)$; thus, structural requirements of the atrin molecule for vascular smooth muscle relaxation and for natriuretic activity seem to be similar.

Atrins are relatively selective in their effects on specific vascular beds. Renal artery and isolated aortic strips in vitro are highly sensitive to the spasmolytic effects of atrin $(29,51,86$, 87) whereas mesenteric, coronary, femoral, vertebral, and carotid 
arteries are relatively unresponsive $(86,87)$. Studies reporting effects of atrin infusion on regional hemodynamics in vivo have not been consistent, however. In conscious rats, atrin infusion was associated with increments in renal, splanchnic, coronary, testicular, lung, and spleen blood flows, without change in cardiac output as measured by the microsphere method (88). In conscious dogs that were chronically instrumented with flow probes, mesenteric, coronary, and iliac blood flows were not affected by atrin infusion, whereas renal vascular resistance declined significantly, leading to enhanced blood flow in that organ (89). In conscious rats with implanted flow-probes, atrin infusion resulted in a significant decrease of mean arterial pressure, brought about solely by a fall in cardiac output, while renal, femoral, and mesenteric vascular resistances increased (90). Similarly, administration of partially purified atrial extracts in conscious spontaneously hypertensive rats (SHR) and in their Wistar-Kyoto controls resulted in a decline of cardiac output, a fall in mean arterial pressure, and elevations of regional vascular resistances (91). Thus, in conscious rats, the fall in mean arterial pressure associated with atrin infusion is not mediated by peripheral vasodilatation, but appears instead to be a consequence of the reduction in cardiac output.

It is evident that conclusions regarding the physiologic role of atrin in reducing total and regional vascular resistances cannot be drawn at this time. Infusion studies are complicated by two main factors. First, since atrin antagonizes vascular smooth muscle contraction elicited by agents such as angiotensin II, vasopressin, and norepinephrine, differences in the degree of baseline activation of these vasoconstrictor systems in vivo may contribute to variable atrin responses. Second, the circulating concentrations of atrin achieved by infusion vary widely in reported studies and are probably vastly greater than those normally occurring in vivo. Thus, effects of atrin infusion may not be the same as those brought about by endogenous atrin release.

\section{Actions on aldosterone biosynthesis and secretion}

The observation that right atrial stretch results in decreased aldosterone secretion in the $\operatorname{dog}(92)$ prompted investigation of possible direct effects of atrial extracts on aldosterone release. Base-line as well as angiotensin II- and ACTH-stimulated aldosterone release by isolated rat adrenal glomerulosa cells were inhibited by atrial but not ventricular extracts in a dose-dependent fashion (93). Synthetic atrin sequences have since been shown to duplicate this effect, with half-maximal inhibition of aldosterone secretion at atrin concentrations in the nanomolar range $(79,94)$. The effect of atrin on aldosterone secretion is universal in that angiotensin II, potassium chloride, ACTH, prostaglandin $\mathrm{E}_{1}$, dibutyryl cyclic AMP (cAMP), and forskolinstimulated aldosterone secretion are all reduced (95). Inhibition of dibutyryl cAMP and forskolin-stimulated aldosterone secretion suggests that atrin does not exert its effect on adrenal glomerulosa cells by blunting cAMP production. Synthesis of aldosterone from progesterone and 25-hydroxycholesterol was not reduced by atrin, suggesting that atrin acts at a step prior to the formation of these intermediates (95). Corticosterone biosynthesis was not affected by atrin, which indicates specificity for aldosterone biosynthesis (94). The inhibitory action of atrin on aldosterone release is dependent on an intact intramolecular disulfide bridge (79), similar to the structural requirement for smooth muscle relaxation (33). Specific receptors for atrin have been demonstrated in membranes prepared from adrenal glomerulosa $(44,64)$, and receptor binding is again critically de- pendent on an intact disulfide bridge (44). Reduction of plasma aldosterone levels in response to atrin infusion has also been documented in anesthetized dogs (12) and in conscious rats (96). Since atrin also inhibits renin release (see below), two mechanisms may be involved in the suppression of plasma aldosterone: a direct action of atrin on adrenal glomerulosa cells and reduced stimulation of adrenal aldosterone release due to lower circulating angiotensin II levels. Although chronic alterations in circulating aldosterone by atrin may modify renal sodium reabsorption, it is unlikely that suppression of aldosterone plays a part in the acute natriuretic response to atrin infusion.

\section{Inhibition of renin release}

Administration of atrin to anesthetized dogs markedly reduces the rate of renal renin secretion and plasma renin activity (12, 97). Renal vasodilation is commonly associated with a reduction in renin secretion, as renin-containing juxtaglomerular cells located in afferent glomerular arterioles respond to changes in arteriolar wall stretch by altering the rate of renin release. In addition, enhanced delivery of $\mathrm{NaCl}$ to the macula densa region of the ascending limb of Henle is thought to exert a negative feedback signal to juxtaglomerular cells to reduce renin secretory rate. Finally, it is possible that atrin acts directly on juxtaglomerular cells to inhibit renin secretion. Preliminary evidence indicates that renin secretion in response to atrin remains constant in the nonfiltering kidney, suggesting that macula densa perfusion is required for this response (98), although a direct effect of atrin on renin secretion by renal cortical slices has also been reported (99). In conscious rats, plasma renin activity was only reduced in states where the renin-angiotensin system was chronically stimulated, as in two kidney-one clip Goldblatt hypertension, and in salt-deleted one kidney-one clip Goldblatt hypertensive rats (100). In normal rats and in rats with volumedependent hypertension (one kidney-one clip Goldblatt hypertension on a normal salt intake), atrin failed to alter plasma renin activity (100). Similarly, in conscious dogs with inferior vena cava ligation, a chronic hyperreninemic state, atrin markedly suppressed plasma renin activity, whereas no response was seen in normal dogs (101). Thus, atrin inhibits renin release under conditions where base-line secretory rates are high, including anesthesia, renin-dependent hypertension, extracellular fluid volume depletion, and inferior vena cava constriction.

\section{Atrin and the kidney}

The most profound physiologic effect of atrin, whether administered by bolus injection or by sustained infusion, is that of markedly enhanced renal salt and water excretion. The mechanisms by which atrin induces this natriuresis and diuresis are as yet incompletely understood. Early studies using bolus administration of atrial extracts reported an immediate but transient increase in the urine flow rate associated with enhanced sodium, chloride, potassium, calcium, magnesium, and phosphorus excretion $(7,102-105)$. The massive solute diuresis suggested inhibition of tubule sodium reabsorption, and it was postulated that a nephron segment beyond the medullary thick ascending limb, namely the medullary collecting duct, was involved (102-104). Nevertheless, inhibition of epithelial ion transport by atrin has not been convincingly demonstrated. Atrial extracts do not inhibit renal Na-K ATPase activity (106), thereby differing from the "natriuretic hormone" described by DeWardener (107). Transport of sodium and chloride in isolated epithelia was also unaffected by atrial extracts $(108,109)$. Synthetic atrin also failed 
to affect ion and fluid transport in several discrete rabbit nephron segments perfused in vitro $(110,111)$. Atrin effects on adenylate cyclase activity in isolated tubule segments have also been examined, again with negative results (112). In clearance studies in rats, atrin produces a brisk phosphaturic response $(102,113)$, even in the absence of a rise in glomerular filtration rate (GFR), which implies direct inhibition of proximal tubule phosphate transport. In support of this possibility, sodium-phosphate cotransport was inhibited in proximal tubule brush border membrane vesicles prepared from rats previously infused with atrin (114). Since a direct in vitro effect of atrin was not demonstrated in this system (114), and since proximal tubules do not express specific atrin receptors (8), it is still not certain whether this represents a direct action of atrin on proximal tubule epithelium, or an effect of increased proximal tubule flow rates (113).

Since atrin is a powerful inhibitor of renal vasoconstriction, it is not surprising that atrin-induced alterations in renal hemodynamics are commonly found. Large doses of atrial extract given as a bolus in the rat (104) and continuous infusion of atrial extracts in rats (115) were shown to increase GFR. Significant increments in GFR are now also regularly found with constant infusion of synthetic atrin in rats and $\operatorname{dogs}(12,97,113)$; also, bolus administration of atrin ${ }_{1-28}$ in humans leads to a transient increase in GFR (116). Alterations in renal blood flow (RBF) are not consistently observed. Total RBF measured by the microsphere method was enhanced in rats after bolus administration of atrial extracts or synthetic atrin $(117,88)$ and with infusion of synthetic atrin 5-28 and atrin 5-27 in dogs (78). When RBF was monitored by flow probe in dogs, atrin infusion produced a transient increase in RBF, which returned to base-line levels or below, 2-5 min after the onset of infusion $(12,89)$. More sustained increments in RBF were found when large doses of synthetic atrin were infused in dogs with high base-line renal vascular resistances (85). Other studies have reported no change in RBF in dogs and rats $(97,113)$. In isolated perfused rat kidneys under base-line vasodilated conditions, intraarterial infusion of atrial extracts leads to an increase in GFR and an increase in renal vascular resistance (RVR) (118), whereas isolated kidneys respond with vasodilation when RVR is maintained at high levels by angiotensin II, vasopressin, or norepinephrine. Consistent in all of the above studies is an increase in the glomerular filtration fraction $(12,97)$. Glomerular micropuncture studies have shown an increase in single nephron GFR and filtration fraction in response to atrin infusion, with relative constancy of glomerular plasma flow. These changes were brought about by dilatation of afferent glomerular arterioles and increments in efferent arteriolar resistances resulting in higher glomerular capillary hydraulic pressures (118). In isolated perfused glomeruli, atrin also resulted in efferent arteriolar vasoconstriction (119).

It has been proposed that increments in GFR can account fully for the natriuresis evoked by atrin on the basis of relative glomerulo-tubular imbalance due in turn to enhanced proximal and loop flow rates (113). However, the finding of a two- to threefold increase in solute delivery to the last accessible portion of the distal tubule in the rat $(104,113)$ cannot account for the 10-50-fold increase in final urinary solute excretion commonly found. Therefore, it is reasonable to conclude that atrin-induced natriuresis is not accounted for by changes in GFR alone, but must be due in large part to atrin actions at other renal sites. A possible clue to further resolution of this issue is the uniform finding of urinary sodium concentrations in excess of plasma after atrin administration. Since urine flow rates also increase greatly, a likely source for the high urinary sodium excretion is the renal papilla. Indeed, Sonnenberg et al. (103) have presented evidence for net addition of sodium along the papillary collecting duct, and preliminary observations reveal that vasa recta Starling forces become less favorable for papillary fluid uptake after systemic atrin infusion in the rat (120). The resulting accumulation of hypernatric papillary interstitial fluid may then be recycled to the papillary collecting duct, thereby enhancing both urinary sodium concentration and absolute sodium excretion rate.

\section{Future prospects}

Almost all of the citations in this review refer to studies performed since DeBold's pioneering report in 1981 (7), which attests not only to the remarkable pace of progress in this area but also to the multidisciplinary nature of the effort, most notably in molecular biology, endocrinology, and renal physiology. Nevertheless, much remains to be learned about the biology and pathobiology of atrin synthesis, secretion, actions, and degradative metabolism. In particular, the subtle effects of atrin on solute and fluid exchanges in kidney await further detailed clarification, as does the relative importance of atrin in blood pressure and volume homeostasis in health and disease, including the potential role of atrin as a pharmaceutically useful diuretic and antihypertensive agent. Synthesis of potent receptor antagonists or other inhibitors of atrin action on target tissues will aid considerably in these efforts, especially in permitting an evaluation of the role of endogenously produced atrin in the various biological responses considered in this brief review.

\section{Acknowledgments}

We are grateful to Michelle Hardiman for expert secretarial assistance. Studies in the authors' laboratory were supported by National Institutes of Health grant AM 30410.

\section{References}

1. Gauer, O. H., J. P. Henry, and C. Behn. 1970. Annu. Rev. Physiol. 32:547-595.

2. Goetz, K. L., A. S. Hermreck, G. L. Slick, and H. S. Starke. 1970. Am. J. Physiol. 219:1417-1423.

3. Henry, J. P., O. H. Gauer, and J. L. Reeves. 1956. Circ. Res. 4: 85-92.

4. Wood, P. 1963. Br. Heart J. 25:273-282.

5. Kinney, M. J., R. M. Stein, and V. A. DiScala. 1974. Circulation. 50:429-434.

6. Thomas, S. 1967. Q. J. Exp. Physiol. Cogn. Med. Sci. 52:313318.

7. DeBold, A. J., H. B. Borenstein, A. T. Veress, and H. Sonnenberg. 1981. Life Sci. 28:89-94.

8. Cantin, M., and J. Genest. 1985. Endocrine Reviews. 6:107-127.

9. Kanagawa, K., and H. Matsuo. 1984. Biochem. Biophys. Res. Commun. 118:131-139.

10. Flynn, T. G., M. L. DeBold, and A. J. DeBold. 1983. Biochem. Biophys. Res. Commun. 117:859-865.

11. Needleman, P., S. P. Adams, B. R. Cole, M. G. Currie, D. M. Geller, M. L. Michener, G. B. Saper, D. Schwartz, and D. G. Standaert. 1985. Hypertension. 7:469-482.

12. Maack, T., D. N. Marion, M. J. Camargo, H. D. Kleinert, J. H. Laragh, E. D. Vaughn, Jr., and S. A. Atlas. 1984. Am. J. Med. 77:10691075.

13. Marin-Grez, M., G. Schubert, J. P. Briggs, and J. Schnermann. 1985. Kidney Int. 27:261a. (Abstr.). 
14. Seidman, C. E., K. D. Bloch, K. A. Klein, J. A. Smith, and J. G. Seidman. Science (Wash. DC). 226:1206-1209.

15. Nemer, M., M. Chamberland, D. Sirois, S. Argentin, J. Drovin, R. A. F. Dison, R. A. Zivin, and J. H. Condra. 1984. Nature (Lond.). 312:654-656.

16. Greenberg, B. D., G. H. Bencen, J. J. Seilhamer, J. A. Lewicki, and J. C. Fiddes. 1984. Nature (Lond.). 312:656-658.

17. Argentin, S., M. Nemer, J. Drovin, G. K. Scott, B. P. Kennedy, and P. L. Davies. 1985. J. Biol. Chem. 260:4568-4571.

18. Seidman, C. E., K. D. Bloch, J. Zisfein, J. A. Smith, E. Haber, C. Homcy, A. D. Duby, E. Choi, R. M. Graham, and J. G. Seidman. 1985. Hypertension (Dallas). 7(Suppl. I): I31-I34.

19. Seidman, C. E., A. D. Duby, E. Choi, R. M. Graham, E. Haber, C. Homcy, J. A. Smith, and J. G. Seidman. 1984. Science (Wash. DC). 225:324-326.

20. Nakayama, N., H. Ohkubo, T. Hirose, S. Inayama, and S. Nakanishi. 1984. Nature (Lond.). 310:699-701.

21. Takayanagi, R., I. Tanaka, M. Maki, and T. Inagami. 1985. Life Sci. 36:1843-1848.

22. Kanagawa, K., Y. Tawaragi, S. Oikawa, A. Mizuno, Y. Sakuragawa, H. Nakazato, A. Fukuda, N. Minamino, and H. Matsuo. 1984. Nature (Lond.). 312:152-155.

23. Geller, D. M., M. G. Currie, N. R. Siegel, K. F. Fok, S. P. Adams, and P. Needleman. 1984. Biochem. Biophys. Res. Commun. 121:802807.

24. Maki, M., R. Takayanagi, K. S. Misono, K. N. Pandey, C. Tibbetts, and T. Inagami. 1984. Nature (Lond.). 309:722-724.

25. Yamanaka, M., B. Greenberg, L. Johnson, J. Seilhamer, M. Brewer, T. Friedemann, J. Miller, S. Atlas, J. Laragh, J. Lewicki, and J. Fiddes. 1984. Nature (Lond.). 309:719-722.

26. Oikawa, S., M. Imai, A. Ueno, S. Tanaka, T. Noguchi, H. Nakazato, K. Kanagawa, A. Fukuda, and H. Matsuo. 1984. Nature (Lond.). 309:724-726.

27. Kanagawa, K., A. Fukuda, N. Minamino, and H. Matsuo. 1984. Biochem. Biophys. Res. Commun. 119:685-688.

28. Thibault, G., R. Garcia, N. G. Seidah, C. Lazure, M. Cantin, M. Chrétien, and J. Genest. 1983. FEBS Lett. 164:286-290.

29. Currie, M. G., D. M. Geller, B. R. Cole, N. R. Siegel, K. F. Fok, S. P. Adams, S. R. Eubanks, G. R. Galluppi, and P. Needleman. 1984. Science (Wash. DC). 223:67-69.

30. Thibault, G., R. Garcia, M. Cantin, J. Genest, C. Lazure, N. G. Seidah, and M. Chrétien. 1984. FEBS (Fed. Eur. Biochem. Soc.) Lett. 167:352-356.

31. Kanagawa, K., A. Fukuda, I. Kubota, Y. Hayashi, and H. Matsuo. 1984. Biochem. Biophys. Res. Commun. 121:585-591.

32. Misono, K. S., R. T. Grammer, H. Fukumi, and T. Inagami. 1984. Biochem. Biophys. Res. Commun. 123:444-451.

33. Misono, K. S., H. Fukumi, R. T. Grammer, and T. Inagami. 1984. Biochem. Biophys. Res. Comm. 119:524-529.

34. Atlas, S. A., H. D. Kleinert, M. J. Camargo, A. Januszewicz, J. E. Sealey, J. H. Laragh, J. W. Schilling, J. A. Lewicki, L. K. Johnson, and T. Maack. 1984. Nature (Lond.). 309:717-719.

35. Lang, R. E., H. Tholken, D. Ganten, F. C. Luft, H. Ruskoaho, and T. Unger. 1985. Nature (Lond.). 314:264-266.

36. Currie, M. G., D. Sukin, D. M. Geller, B. R. Cole, and P. Needleman. 1984. Biochem. Biophys. Res. Commun. 124:711-717.

37. Gutkowska, J., K. Horky, G. Thibault, P. Januszewicz, M. Cantin, and J. Genest. 1984. Biochem. Biophys. Res. Commun. 125:315-323.

38. Gutkowska, J., M. Bourassa, D. Roy, G. Thibault, R. Garcia, M. Cantin, and J. Genest. 1985. Biochem. Biophys. Res. Commun. 128: 1350-1357.

39. Sugawara, A., K. Nakao, N. Morii, M. Sakamoto, M. Suda, M. Shimokura, Y. Kiso, M. Kihara, Y. Yamori, K. Nishimura, J. Someda, T. Ban, and H. Imura. Biochem. Biophys. Res. Commun. 129:439-446.

40. Schwartz, D., D. M. Geller, P. T. Manning, N. R. Siegel, K. F. Fok, C. E. Smith, and P. Needleman. 1985. Science (Wash. DC). 229: 397-400.
41. Yamaji, T., M. Ishibashi, and F. Takaku. 1985. J. Clin. Invest. 76:1705-1709.

42. Maack, T., M. J. Camargo, H. D. Kleinert, J. H. Laragh, and S. A. Atlas. 1985. Kidney Int. 27:607-615.

43. Sugiyama, M., H. Fukume, R. T. Gammer, K. S. Misono, Y. Yabe, Y. Morisawa, and T. Inagami. 1984. Biochem. Biophys. Res. Commun. 123:338-344.

44. De L'ean, A., J. Gutkowska, N. McNicoll, P. W. Schiller, M. Cantin, and J. Genest. 1984. Life Sci. 35:2311-2318.

45. Thibault, G., R. Garcia, F. Carrier, N. G. Seidah, C. Lazure, M. Chrétien, M. Cantin, and J. Genest. 1984. Biochem. Biophys. Res. Commun. 125:938-946.

46. Kisch, B. 1956. Exp. Med. Surg. 114:99-112.

47. Jamieson, J. D., and G. E. Palade. 1964. J. Cell Biol. 23:151172.

48. Huet, M., and M. Cantin. 1974. Lab. Invest. 30:525-532.

49. Tang, J., H. Fei, C. W. Xie, M. Z. Suen, J. S. Han, R. J. Webber,

D. Chang, and J. K. Chang. 1984. Peptides (NY). 5:1173-1177.

50. Metz, J., V. Mutt, and W. E. Forssmann. 1984. Anat. Embryol. 170:123-127.

51. Currie, M. G., D. M. Geller, B. R. Cole, J. C. Boylan, W. YuSheng, S. W. Holmberg, and P. Needleman. 1983. Science (Wash. DC). 221: 71-73.

52. Cantin, M., A. M. Michelakis, H. Ong, M. Ballak, J. Beuzeron, and S. Benchimol. 1982. Adv. Myocardiol. 3:519-529.

53. DeBold, A. J. 1979. Proc. Soc. Exp. Biol. Med. 161:508-511.

54. Saper, C. B., D. B. Standaert, M. G. Currie, D. Schwartz, D. M. Geller, and P. Needleman. 1985. Science (Wash. DC). 227:1047-1049. 55. Dietz, J. R. 1984. Am. J. Physiol. 247:R1093-R1096.

56. Currie, M. G., D. Sukin, D. M. Geller, B. R. Cole, and P. Needleman. 1984. Biochem. Biophys. Res. Commun. 124:711-717.

57. Manning, P. T., D. Schwartz, N. C. Katsube, S. W. Holmberg, and P. Needleman. 1985. Science (Wash. DC). 229:395-397.

58. Sonnenberg, H., and A. T. Veress. 1984. Biochem. Biophys. Res. Commun. 124:443-449.

59. Shenker, Y., R. S. Sider, E. A. Ostafin, and R. J. Grekin. 1985. J. Clin. Invest. 76:1684-1687.

60. Yamaji, T., M. Ishibashi, H. Nakaoka, K. Imataka, M. Amano, and J. Fujii. 1985. Lancet. I:8439:1211.

61. Tanaka, I., K. S. Misono, and T. Inagami. 1984. Biochem. Biophys. Res. Commun. 124:663-668.

62. Ballermann, B. J., K. D. Bloch, J. G. Seidman, and B. M. Brenner. 1986. Kidney Int. In press. (Abstr.)

63. Bianchi, G., J. Gutkowska, R. Garcia, G. Thibault, J. Genest, and M. Cantin. 1985. Histochemistry. 82:441-446.

64. Schiffrin, E. L., L. Chartier, G. Thibault, J. St.-Louis, M. Cantin, and J. Genest. 1985. Circ. Res. 56:801-807.

65. Napier, M. A., R. L. Vandlen, G. Albers-Schonberg, R. F. Nutt, S. Brady, T. Lyle, R. Winquist, E. P. Faison, L. A. Heinel, and E. H. Blaine. 1984. Proc. Natl. Acad. Sci. USA. 81:5946-5950.

66. Ballermann, B. J., R. L. Hoover, M. J. Karnovsky, and B. M. Brenner. 1985. J. Clin. Invest. 76:2049-2056.

67. Hirata, Y., M. Tomita, H. Yoshimi, and M. Ikeda. 1984. Biochem. Biophys. Res. Commun. 125:562-568.

68. Hirata, Y., M. Tomita, H. Yoshimi, and M. Ikeda. 1984. Biochem. Biophys. Res. Commun. 125:562-568.

69. Leitman, D. C., S. A. Waldman, T. Kuno, and F. Murad. 1985. Clin. Res. 33:599a. (Abstr.)

70. Yip, C. C., L. P. Laing, and T. G. Flynn. 1985. J. Biol. Chem. 260:8229-8232.

71. Waldman, S. A., R. M. Rapoport, and F. Murad. 1984. J. Biol. Chem. 259:14332-14334.

72. Hamet, P., J. Tremblay, S. C. Pang, R. Garcia, G. Thibault, J. Gutkowska, M. Cantin, and J. Genest. Biochem. Biophys. Res. Commun. 123:515-527.

73. Garcia, R., G. Thibault, J. Gutkowska, P. Hamet, M. Cantin, and J. Genest. 1985. Proc. Soc. Exp. Biol. Med. 178:155-159. 
74. Tremblay, J., R. Gerzer, P.. Vinay, S. C. Pang, R. Beliveau, and P. Hamet. 1985. FEBS (Fed. Eur. Biochem. Soc.) Lett. 181:17-22.

75. Winquist, R. J., E. P. Faison, S. A. Waldman, K. Schwartz, F. Murad, and R. M. Rapoport. 1984. Proc. Natl. Acad. Sci. USA. 81: 7661-7664.

76. Ohlstein, E. H., and B. A. Berkowitz. 1985. Hypertension (Dallas). 7:306-310.

77. Appel, R. G., and M. J. Dunn. 1985. Clin. Res. 33:618a. (Abstr.) 78. Wakitani, K., T. Oshima, A. D. Loewy, S. W. Holmberg, B. R. Cole, S. P. Adams, K. F. Fok, M. G. Currie, and P. Needleman. 1985. Circ. Res. 56:621-627.

79. Chartier, L., E. Schiffrin, and G. Thibault. 1984. Biochem. Biophys. Res. Commun. 122:171-174.

80. Anand-Srivastava, M. B., D. J. Franks, M. Cantin, and J. Genest. 1984. Biochem. Biophys. Res. Commun. 121:855-862.

81. Anand-Srivastava, M. B., M. Cantin, and J. Genest. 1985. Life Sci. 36:1873-1879.

82. Oshima, T., M. G. Currie, D. M. Geller, and P. Needleman. 1984. Circ. Res. 54:612-616.

83. Geller, D. M., M. G. Currie, K. Wakitani, B. R. Cole, S. P. Adams, K. F. Fok, N. R. Siegel, S. R. Eubanks, G. R. Galluppi, and P. Needleman. 1984. Biochem. Biophys. Res. Commun. 120:333-338.

84. Thibault, G., R. Garcia, F. Carrier, N. G. Seidah, C. Lazure, M. Chrétien, M. Cantin, and J. Genest. 1984. Biochem. Biophys. Res. Commun. 125:938-946.

85. Wakitani, K., B. R. Cole, D. M. Geller, M. G. Currie, S. P. Adams, K. F. Fok, and P. Needleman. 1985. Am. J. Physiol. 249:F49F53.

86. Garcia, R., G. Thibault, M. Cantin, and J. Genest. 1984. Am. J. Physiol. 247:R34-R39.

87. Ishihara, T., K. Aisaka, K. Hattori, S. Hamasake, M. Morita, T. Noguchi, K. Kanagawa, and H. Matsuo. 1985. Life Sci. 36:1205-1215.

88. Garcia, R., G. Thibault, J. Gutkowska, M. Cantin, and J. Genest. 1985. Life Sci. 36:1687-1692.

89. Hintze, T. H., M. G. Currie, and P. Needleman. 1985. Am. J. Physiol. 248:H587-H591.

90. Lappe, R. W., J. F. M. Smits, J. A. Todt, J. J. M. Debets, and R. L. Wendt. 1985. Circ. Res. 56:606-612.

91. Pegram, B. L., M. B. Kardon, N. G. Trippodo, F. E. Cole, and A. A. MacPhee. 1985. Am. J. Physiol. 249:H265-H271.

92. Anderson, C. H., M. McCally, and G. L. Farrell. 1959. Am. J. Physiol. 64:202-207.

93. Atarshi, K., P. J. Mulrow, R. Franco-Saenz, R. Snajdar, and J. Rapp. 1984. Science (Wash. DC). 224:992-994.

94. DeLean, A., K. Racz, J. Gutkowska, T. T. Nguyen, M. Cantin, and J. Genest. 1984. Endocrinology. 115:1636-1638.

95. Goodfriend, T. L., M. E. Elliott, and S. A. Atlas. 1984. Life Sci. 35:1675-1682.

96. Chartier, L., E. Schiffrin, G. Thibault, and R. Garcia. 1984. Endocrinolgoy. 115:2026-2028.
97. Burnett, J. C., Jr., J. P. Granger, and T. J. Opgenorth. 1984. Am. J. Physiol. F863-F866.

98. Opgenorth, T. J., J. C. Burnett, Jr., and J. P. Granger. 1985. Fed. Proc. 44:1738a. (Abstr.)

99. Henrich, W., L. McAllister, P. Smith, P. Needleman, and W. Campbell. 1985. Clin. Res. 33:528a. (Abstr.).

100. Volpe, M., G. Odell, H. D. Kleinert, F. Muller, M. J. Camargo, J. H. Laragh, T. Maack, E. D. Vaughn, Jr., and S. A. Atlas. 1985. $H y-$ pertension (Dallas). 7(Suppl I):I-43-I-48.

101. Freeman, R. H., J. O. Davis, and R. C. Vari. 1985. Am. J. Physiol. 248:R495-R500.

102. Keeler, R., and A. M. Azzarolo. 1983. Can. J. Physiol. Pharmacol. 61:996-1002.

103. Sonnenberg, H., W. A. Cupples, A. J. DeBold, and A. T. Veress. 1982. Can. J. Physiol. Pharmacol. 60:1149-1152.

104. Briggs, J. P., B. Steipe, G. Schubert, and J. Schnermann. 1982. Pflueger's Arch. Eur. J. Physiol. 395:271-276.

105. Hammond, T. G., A. Haramati, and F. G. Knox. 1985. Am. J. Physiol. 249:F315-F318.

106. Pollock, D. M., M. M. Mullins, and R. O. Banks. 1983. Renal Physiol. 6:295-299.

107. DeWardener, H. E. 1977. Clin. Sci. Mol. Med 53:1-8.

108. Pammani, M. B., D. L. Clough, J. S. Chen, W. T. Link, and

F. J. Haddy. 1984. Proc. Soc. Exp. Biol. Med. 176:123-131.

109. Throckmorton, D. C., and J. P. Gilmore. 1983. Fed. Proc. 42: 475. (Abstr.)

110. Baum, M. 1985. Clin. Res. 33:477a. (Abstr.)

111. Kondo, Y., M. Imal, K. Kanagawa, and H. Matsuo. Pfluegers Arch. Eur. J. Physiol. In press.

112. Umemura, S., D. D. Smyth, and W. A. Pettinger. 1985. Fed. Proc. 44:1102. (Abstr.)

113. Huang, C.-L., J. Lewicki, L. K. Johnson, and M. G. Cogan. 1985. J. Clin. Invest. 75:769-773.

114. Hammond, T. G., A. N. K. Yusuf, F. G. Knox, and T. P. Dousa. 1985. J. Clin. Invest. 75:1983-1989.

115. Beasley, D., and R. L. Malvin. 1985. Am. J. Physiol. 248:F24F30.

116. Kuribayashi, T., M. Nakazato, M. Tanaka, M. Nagamine, T. Kurihara, K. Kangawa, and H. Matsuo. 1985. N. Engl. J. Med. 312: 1456-1457.

117. Borenstein, H. B., W. A. Cupples, H. Sonnenberg, and A. T. Veress. 1983. J. Physiol. (London). 334:133-140.

118. Camargo, M. J., H. D. Kleinert, S. A. Atlas, J. E. Sealey, J. H. Laragh, and T. Maack. 1984. Am. J. Physiol. 246:F447-F456.

119. Fried, T. A., R. N. McCoy, R. W. Osgood, H. J. Reineck, and J. H. Stein. 1985. Clin. Res. 33:584a. (Abstr.)

120. Dunn, B. R., J. L. Troy, I. Ichikawa, and B. M. Brenner. 1986. Kidney Int. In press. (Abstr.) 